\title{
Seasonal Variations in the Protein content from Different tissues of Octopus aegina in Pazhayar coastal waters, Nagapattinam District, Tamilnadu
}

\author{
S. Kavitha ${ }^{1}$, A. Christy Ponni ${ }^{2 *}$ \\ ${ }^{1} \mathrm{PG}$ and Research Department of Zoology, TBML College, Porayar, India \\ ${ }^{2}$ PG and Research Department of Zoology, TBML College, Porayar, India \\ Available online at: www.isroset.org \\ Received: 06/Sept/2018, Accepted: 25/Sept/2018, Online: 31/Oct/2018
}

\begin{abstract}
Of all the components, changes in protein play an important role in the seasonal variation of the chemical composition. In general, the water content of the tissue of bivalves usually gives an indication of the time of spawning. Variation in dry tissue weight of mollusc is always associated with biochemical components. Seasonal changes in the biochemical constituent are the characteristics of the seasonal activities of Molluscs. The present study was carried out on Octopus aegina to assess the seasonal variations in the protein content during January 2017 to December 2017 . The total protein was estimated in muscle, gill, liver and gonad. The highest concentration of protein content was present in gonad followed by muscle, gill and liver. Among the seasonal changes, protein values were high during monsoon.
\end{abstract}

Key words: Octopus aegina, Muscle, Gill, Liver and Gonad.

\section{INTRODUCTION}

Molluscs are delicious and protein rich food among the sea foods [1]. Protein is the essential substance of life and accordingly exists in the largest quantity of all nutrients as a component of the living organisms. Cephalopods bodies (flesh) are composed of 75 to $85 \%$ Protein on a dry weight basis. In contrast to fishes cephalopods contain $20 \%$ more protein, $80 \%$ less ash, 50 - 90\% less lipids \& 50 - 90\% less carbohydrate [2]. Cephalopod water content is approximately $80 \%$ with Protein (16.6\%) being the next most abundant component [3] Limited studies on cephalopod mollusc's biochemistry were carried out by Pierce et al. [4]. Siegert et al. [5] in cephalopods tissues VanHeukelem [6] in Octopus maya and Rosa et al. [7] in Octopus vulgaris.The present study was carried out to analyse the total Protein from seasonal collection of Octopus aegina from Pazhayar coastal waters where in earlier works are not available.

\section{MATERIALS AND METHODS}

To analyse the seasonal variations in the protein content of muscle, gill, liver and gonad. 20 medium sized animals were collected from the field, washed thoroughly with fresh water and immediately kept in ice box were brought to the laboratory. These animals were dissected and the respective tissues were pooled out for Protein estimation. The estimation of total Protein was estimated by the method of Lowry et al. [8].

\section{RESULTS AND DISCUSSION}

The mussels are ecologically important because of their widespread distribution and biological filtration activity and also economically, used as food and in the production of freshwater pearls. Molluscs are potential sources of valuable proteins, carbohydrates and minerals and are abundantly available in India. The biochemical composition of mollusc is influenced by its size, growth and reproductive status. Bivalves play an important role in the ecosystem equilibrium and constitute an important economic end point. The bivalves have not been the subject of intense studies despite the presence of rich diversity of edible and commercial species in India. The seasonal variation in the Protein content has been shown in the table 1 and figure 1 to 4. In octopus vulgaris the protein content is high in female than the male. Similar studies were carried out by Pierce et al., [4] in cephalopod biochemistry. 
Muscle : In the Muscle of male Octopus aegina the Protein values fluctuated from $28.18 \%$ to $45.68 \%$ and in females from 30.23 to $46.86 \%$.

Gill : The Percentage of protein values in males fluctuated from 23.09 to $38 . .53 \%$ and in females from 25.01 to $40.01 \%$.

Liver : In males Protein values varied from $21.71 \%$ to $33.34 \%$ and in females from 22.26 to $34.56 \%$.

Gonad : When compared to all other body parts, the gonad showed higher protein percentage. In males it was from 29.21 to $47.90 \%$ and in females from 32.90 to $48.46 \%$. In general protein values were higher in females than the males. Thus the gonad seems to serve as a storage organ of protein in Octopus aegina.

It was also reported as by Giese [9] that protein is dominant organic constituent in molluscs. The female have higher percentage of protein conent than that of male in all the seasons. A comparison of protein content in the various body parts of gonad followed by Muscle, Gill and Liver in the present study. Protein values were high during monsoon. It could be due to intense proliferation of gonad and the low protein value in summer (May and June) due to the spawning. Similar observations were made in Octopus vulgaris [7]. Freshwater mussels are ecologically important group of burrowing organisms in aquatic ecosystems. The mussels are ecologically important because of their widespread distribution and biological filtration activity and also economically used as food and in the production of freshwater pearls. The knowledge of biochemical composition of any edible organism is extremely important since the nutritive value is reflected in its biochemical contents. The biochemical composition in the molluscs has been mainly studied to assess the nutritive status and also to supplement information on reproductive biology. The mussels provide high quality protein with all the dietary amino acids for maintenance and growth of human body.

Table no. 1 Seasonal variations in the protein content of Octopus aegina $(\%)$

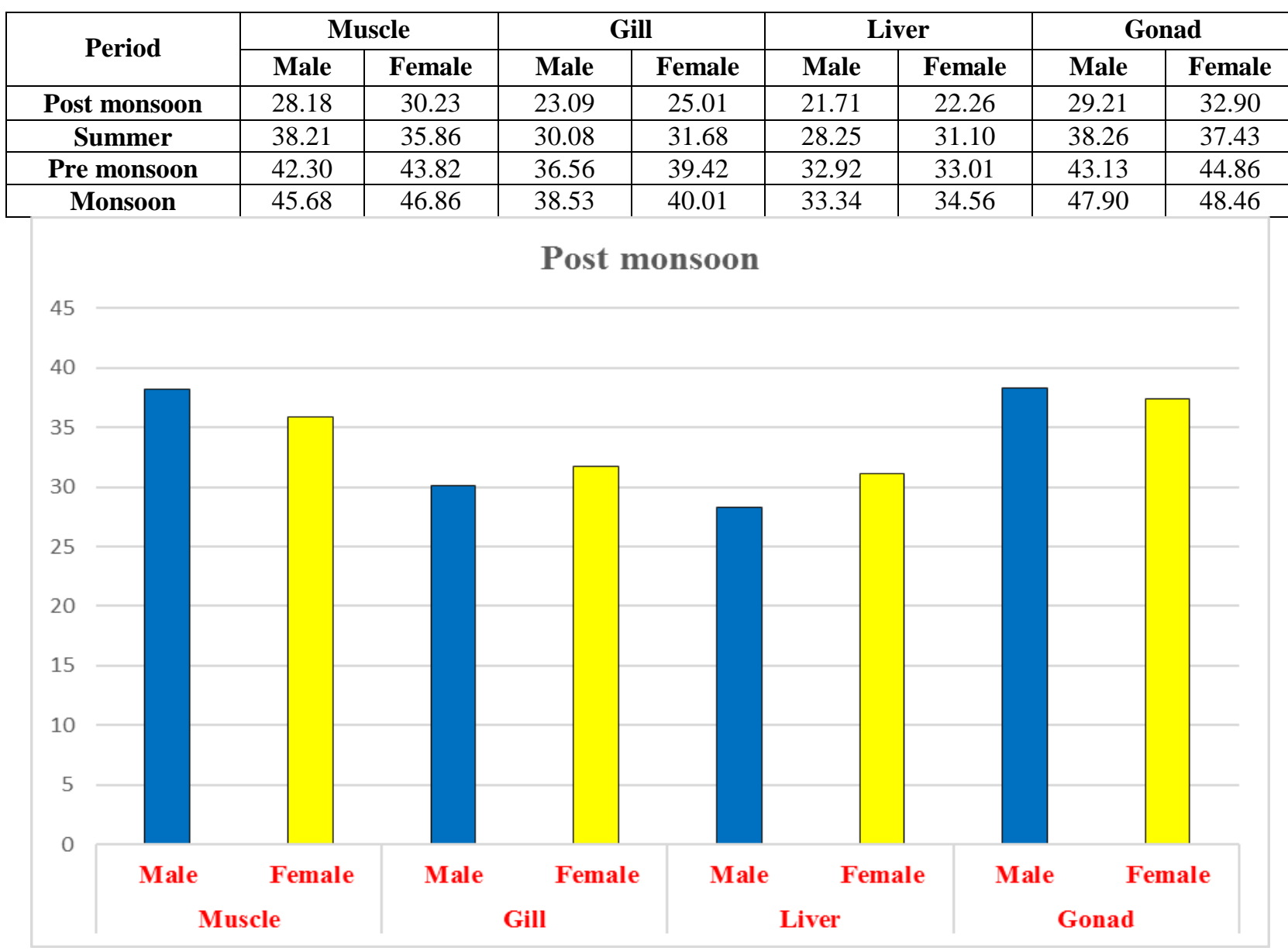

Figure 1 Seasonal variations in the protein content (\%) of O.aegina during Post Monsoon Season. 


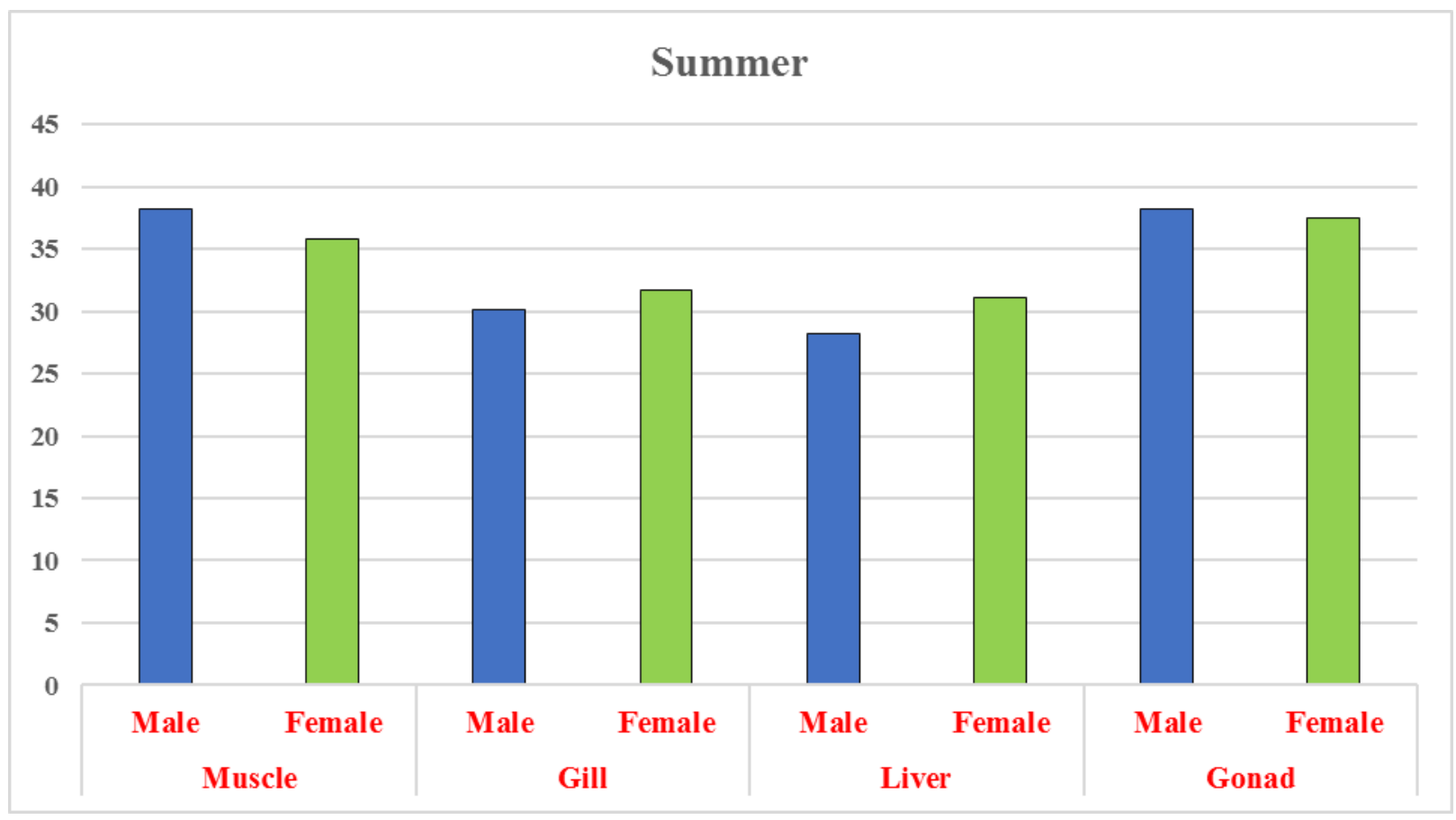

Figure 2 Seasonal variations in the Protein content of O.aegina during Summer Season (\%).

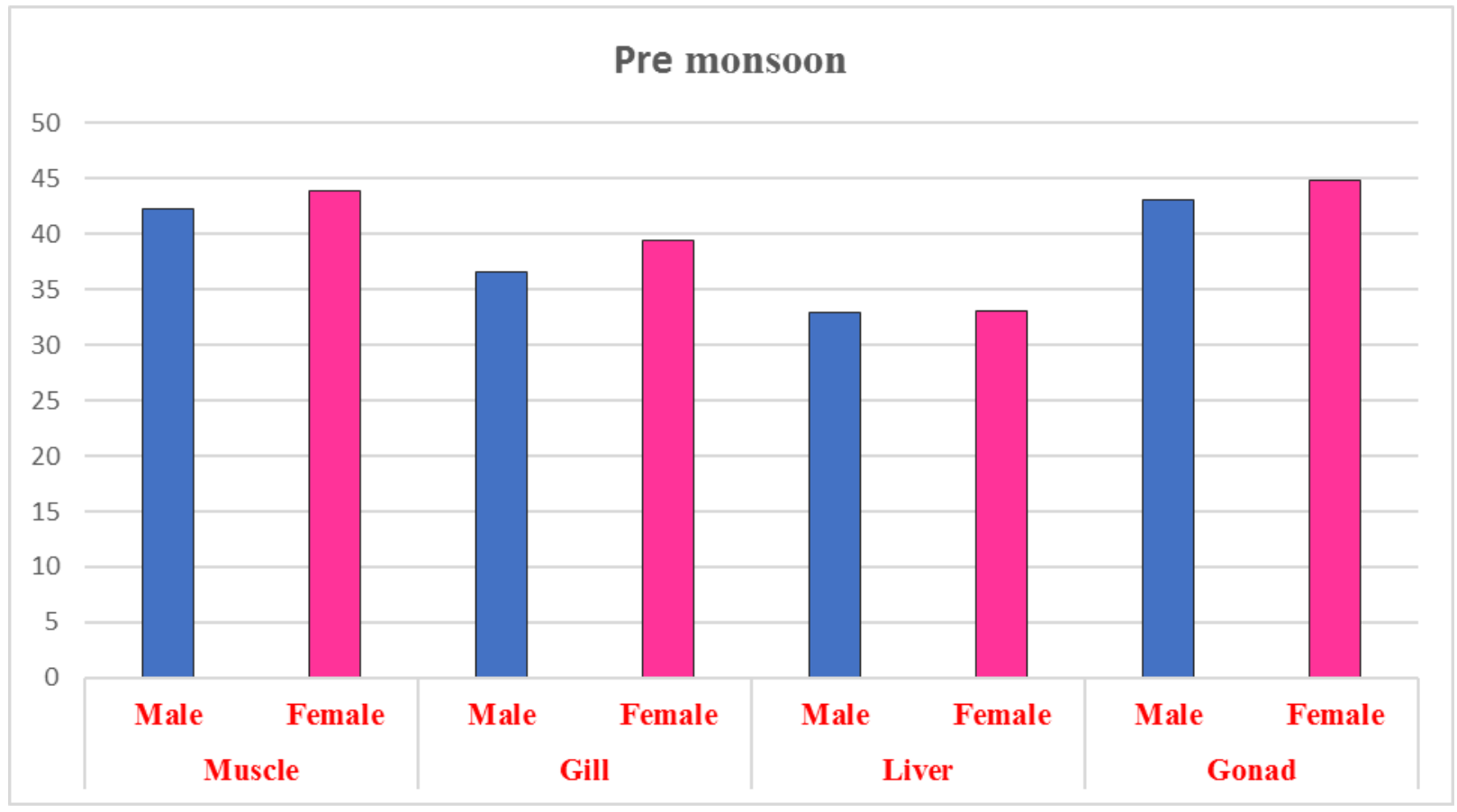

Figure 3 Seasonal variations in the Protein content (\%) of O.aegina during Pre Monsoon Season 


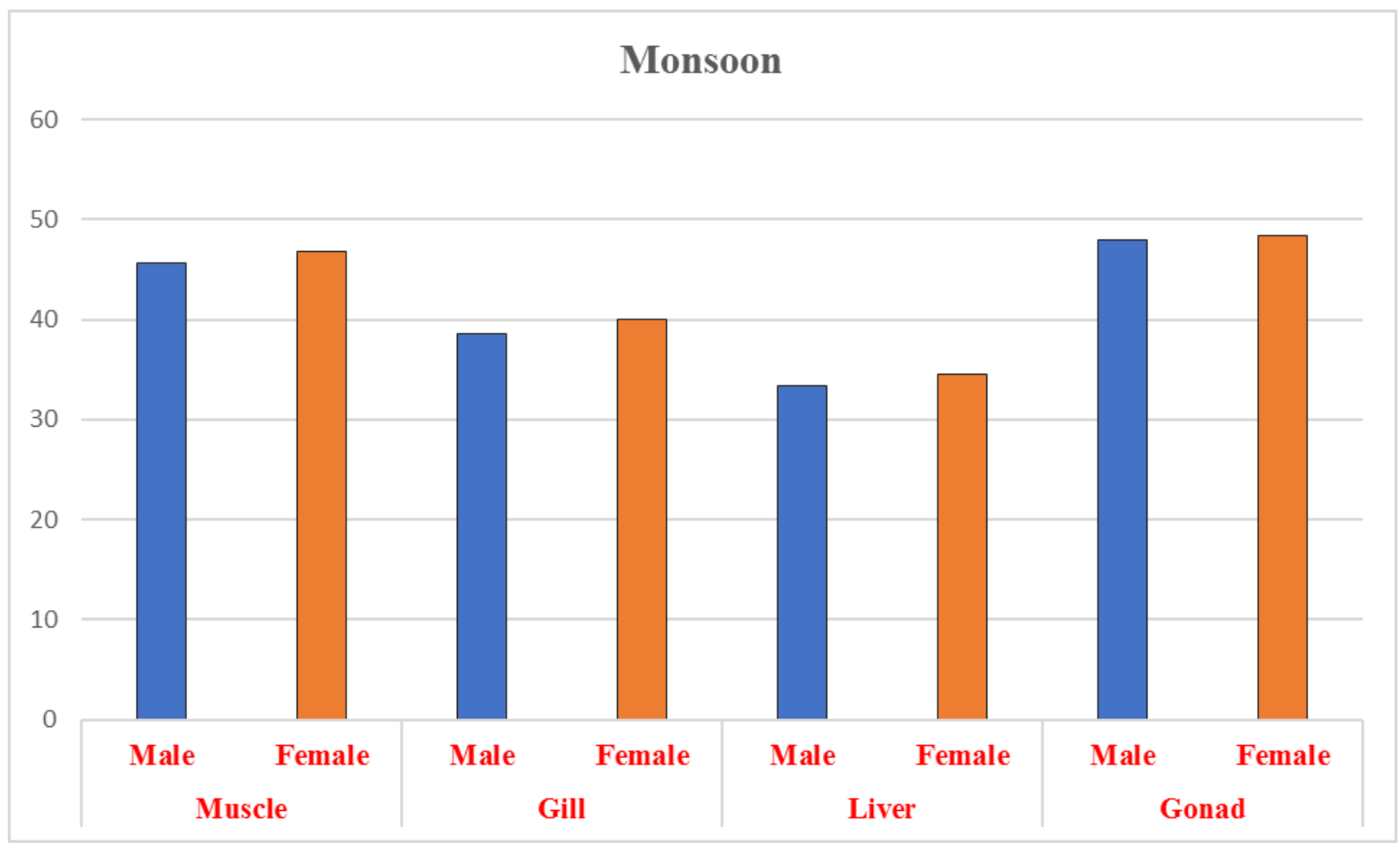

Figure 4 Seasonal variations in the Protein content (\%) of O.aegina during monsoon season

\section{CONCLUSION}

The results of the present study concluded that highest concentration of protein content present in gonad followed by muscle, gill and liver. Protein values were high during monsoon. It could be due to intense proliferation of gonad and the low protein value in summer (May and June) due to the spawning.

\section{REFERENCES}

[1] I. Jagadis, Biology of an intertial clam Gatrarium tumidum (Roding) from south east pp 155, 2005.

[2] P. G Lee, Nutrition of cephalopods Fuelling the system. Mar. Fresh. Behav. Physiol 2, pp 35-51, 1994.

[3] M. Iwasaki, R. Harada, Proximate and amino acid composition of the roe and muscle of selected marine species. J. Food Sci. pp 50, 1985.

[4] G. J. Pierce, L. N. Key, P. R. Boyle, K. J. Siegert, J. M. Goncalves, F. M. Porteiro, H. R Martins,. Protein and RNA ratio in cephalopod tissues: Sources of variation and relationship with growth rate. J. Exp. Mar. Biol. Ecol. 237, pp 185 - 201, 1999.

[5] K. J. Siegert, J. Norman, G. J. Piece, P. R. Boyle, L. Key,. Application of biochemical indices to measure growth rates in cephalopods. ICES CM / K: 24,8, pp 1994.

[6] W. F. Van Heukelem,. Laboratory maintenance breeding, rearing \& bio medical research potential of the Yucatan Octopus (Octopusmaya). Lab. Animal Sci, 27, pp 852-859, 1977.

[7] R. Rosa, L. Nunes, C. Sousa Reis, Seasonal changes in the biochemical composition of Octopus vulgaris Cuvier, 1797, from three Areas of the Portuguese coast. $\quad$ Bull. Mar. Sci., 71(2), pp 739 -751, 2002.

[8] O. H. Lowry, N. J. Rosenbrough, A. L Farr, R. J. Randall,. Protein measurement with folin phenol reagent. J. Biol. Chem.193, pp 265 - 275, 1951.

[9] A. C. Giese, A new approach to the biochemical composition of the molluscan body. Oceanogr. Mar. Biol. Annu. Rev, 7, pp 175-229, 1969. 